\title{
Evaluation of a Group of Medical School Students' Opinions on Quality of Education
}

\author{
Fatma Bolaç ${ }^{1}$ \\ Mersin University
}

\author{
Oya Ögenler ${ }^{2}$ \\ Mersin University
}

\begin{abstract}
Medical education has a special importance among sectors, and the fulfillment of certain quality standards related with reflecting basic universal perfections is the most important expectation. The aim of our study is to evaluate the expectations of the students in medical school for medical education and the realization status of their expectations within the academic process in terms of quality and standards. The universe of the study consists of 230 students. Two open ended questions were asked to students in order to understand what their expectations were after being successful in ÖSYS and whether their expectations were fulfilled or not. In summarization of data frequency, average \pm standard deviation, and median was used. In comparison of data the Student-t test was used and $\mathrm{p}<.05$ was assumed to be statistically significant. In our study 116 (41.4\% female, $58.6 \%$ male) students were reached with an average age of $22.12 \pm 1.43$ between 20-28). Their ÖSYS point averages are $501.85 \pm 11.85$. Their birth places are 54.3\% Mediterranean region, and $28.4 \%$ Southeastern Anatolian region. According to quality standards 70 students (60.3\%) stated that they have expectations about the features of the profession. 50\% of them stated that their expectations are fulfilled, 35 of them (30.2\%) stated that their expectations are not fulfilled and 23 of them (19.8\%) did not state a clear opinion. The ÖSYS point averages of students who stated that their expectations were fulfilled were found to be lower than the ones who stated that their expectations were not fulfilled $(\mathrm{p}=.000)$. In our study it was observed that students have an expectation about post-graduation, academic process and social environment in terms of quality standards in medical education. As a result it is considered that improving the knowledge levels of students about quality will develop their expectations positively and will contribute to medical education quality.
\end{abstract}

\section{Keywords}

Education $\bullet$ Quality $\bullet$ Standard $\bullet$ Medical education $\bullet$ Medical student

\footnotetext{
1 Correspondence to: Fatma Bolaç, Institute of Management Business and Law, Business Administration, Rostov, Mersin University Higher Education Secretary. Mersin University Çiftlikköy Campus Medical Faculty Yenişehir Mersin 33343 Turkey. Email: fatmabolac@mersin.edu.tr

2 Department of History of Medicine and Ethics, Faculty of Medicine, Mersin University, Mersin Turkey. Email: oyaogenler@gmail.com

Citation: Bolaç, F., \& Ögenler, O. (2016). Evaluation of a Group of Medical School Students' Opinions on Quality of Education. Educational Sciences: Sanitas Magisterium, 2, 63-70. http://dx.doi.org/10.12738/SM.2016.1.0021
} 
In line with scientific and technological development, it is necessary for units that provide medical education to update their curriculum and goals with regard to ethical principles in order to meet modern services levels (The World Medical Education Federation, 2007). In the context of this goal, the education services should be evaluated and measurable outputs should be revealed. Medicine has a special position among other sectors; therefore, its curriculum for professional education should be in accordance with universal competence. The quality of education in line with modern and ethical medical principles that were provided to doctor candidates will determine the ability of doctors to fill their social roles and responsibilities after their graduation (Özdemir Turan, 2005). The word "quality" was derived from the Latin word "qualitas, which refers to how a thing comes into being. The lexical meaning of quality is defined as how something emerges and the properties that make it distinctive from other things (Doğan, 2002; TDK, n.d.). The concept of quality refers to positive attributions according to its purpose of use. At the same time quality includes perfectness of a good or service, its compatibility with determined conditions or total number of its properties depending upon the fulfilment of probable needs (Koçel, 1999; Öner, 2007).

The assurance of a doctor candidate's education is due to a number of standardization rules that are determined in the context of modern ethical principles. It is essential for medical education, in terms of the service quality in education, to include certain standards of quality for meeting capacities of a professional doctor.

In order to meet some capacities, known as "universal basic competencies", in our medical education, which has a traditional and modern structure, it is necessary to achieve certain standards of quality and maintain this standard level at the same time. Basic competencies, which medical faculty graduates should have, must be adequate to meet the needs of the society that they were educated and prepared to serve (Özdemir Turan, 2005). Medical Education is gaining importance in terms of determination of general education standards and their implementation and development, mutual recognition of diplomas, being able to make a comparison between institutions and evaluation of competencies of medical faculties. Standards that fulfill defined capacities, which are defined as basic competencies for profession doctors, are structured in nine fields for pre-graduation education. These are "Mission and Vision," "Educational Program (Curriculum)," "Evaluation of Students," "Students," Academic Staff," "Source of Education," "Program Evaluation," "Management and Administration," and "Constant Improvement" (Lilley \& Harden, 2003).

For the standards that are developed on the basis of these titles two levels are predicted. The first level includes the most necessary standards that are to be adapted by medical faculties, including essential factors concerning the doctor-patient relationship and medical practices enabling professional capacity. The second level consists of standards that aim 
to improve the quality of medical faculties and their education programs. This two-level handling of standards results in the emergence of convenient levels that are developed by medical faculties with different educational traditions, socio-economic and cultural conditions (Gültekin, Söylemez, Dereboy, \& Çiçek, 2006). Formation of certain standards in medical education allows for evaluation of education programs, improvement of curriculums and their adaptation to modern levels. Formation of national and international standards for medical education and subsequent achievement in quality of education is a step for development and constant improvement. Standards often are implemented towards the academic process, curriculum content and post-graduation education in education programs. Since 2012, The Medical Faculty of Mersin University has been accredited and provides education that is compatible with medical education standards.

Today, the influence of science and technology has become dominant in medical education; therefore, it is essential to form general education standards that are compatible with modern ethical principles of medicine. Acquisition of certain level of standards in medical education, on both national and international levels, will improve the quality of doctor candidates, who are the latest generation receiving this education, and reward them with the title of "world doctors" (Özdemir Turan, 2005). The aim of this study is to investigate expectations of students in medical faculty education and their level of satisfaction in terms of quality standards.

\section{Method}

The sample of the study consisted of 230 third grade students who are studying at the Medical Faculty during 2014-2015 academic year. During the introduction part, called "What is a Profession?", which exists in the curriculum of medical history and ethics course, the students were asked two open ended questions concerning their expectations and whether these expectations were satisfied. The first question was "What were your expectations after you passed the Student Selection and Placement Examination (SSPE) and the second question was "What do you think about the level of satisfaction of your expectations during the process of medical education?". 116 students replied to these questions.

In our study, student answers were coded and classified in terms of quality standards of education (concerning profession of doctorship, academic process and social life). The researcher coded their level of satisfaction of expectations as positive, negative, or neutral. Answers that were not related to questions were excluded from the study.

The ages and birth places of students were compared with the codes stemming from their SSPE scores. In summarizing data and comparison of frequencies, means \pm standard deviations, the Student-t test was employed and found to be statistically significant $(p<.05)$. 


\section{Findings}

A total number of 116 students participated in the study; $41.4 \%$ were females and $58.6 \%$ were males. The mean of students' ages were $22.12 \pm 1.43$ (between 20 and 28), SSPE score averages were $501.85 \pm 11.85$. 63 students (54.3\%) were born in the Mediterranean Region, 33 (28.4\%) were born in the South-eastern Region and the rest (20 students, 17.2\%) came from other regions.

According to quality standards, 70 students $(60.3 \%)$ expressed their expectations about professional properties, 20 students (17.2\%) about the social environment and $26(20.4 \%)$ students about the academic process. $50 \%$ of all participants stated that their expectations were satisfied, whereas 35 (30.2\%) students expressed that their expectations were not satisfied. 23 (19.8\%) students did not form a clear view whether their expectations were satisfied or not. It was found that SPSE score averages of students who stated that their expectations were satisfied, were lower than students who expressed that their expectations were not satisfied $(p<.05)$. No significant difference was identified with SPSE score averages of students in terms of their expectations towards medical education $(p<.05)$.

\section{Discussion}

Our study evaluated expectation of third grade students at the Medical Faculty of Mersin University and the realization of their expectations in terms of quality and standards. It was found that students had more positive opinions about satisfaction of their expectations towards professional life, the academic process and the social environment. The standards, which were identified by this study among the student expectations, are compatible with the basic fields of pre-graduation, post-graduation and constant medial education, which were determined by the World Medical Education Federation on international standards in medical education programs (Lilley \& Harden, 2003). It is hoped that students have positive feelings about their expectations and satisfaction, since this shows a high quality of education. According to a study in the literature, medical faculty and faculty of dentistry students' expectations were not satisfied during the hospital training stage (Ekinci \& Burgaz, 2007). In our study, despite the fact that students did not undertake training at hospital, which includes doctor-patient relations in a busy environment, and did not receive practical education concerning their professions, it is important that they had positive feelings. Some similar studies analyzed post-graduate education negatively, therefore it is essential to evaluate the medical education process separately in two fields: the clinical period and the pre-clinical period (Gültekin et al., 2006). In addition, the positive situation in our study might stem from the fact that professional difficulties concerning education facilities and doctor-patient relations in the hospital environment were not reflected in student education. 
Doctors are expected to be trained as careful listeners and observers, sensitive communicators and active clinicians (Sayek, Odabaş1, \& Kiper, 2010). In our study, students evaluated their expectations about positive and negative situations in detail concerning the academic process by mentioning exam systems and working conditions.

During coding it was noteworthy that students evaluated their situation realistically in accordance with the facilities and conditions. In addition, in our study, students mentioned their expectations towards a profession which is particularly concerned with moral values such as helping people, receiving respect, and treatment of illnesses. Students motivated themselves positively to keep the moral values of this profession high. Students came from similar regions; their emphasis on moral values and internalization of them may stem from the similarity of socio-cultural structure. Similar to our study, another in the literature found Medical Faculty of Gazi University students considered "moral gain of the profession" as the most important reason for their decision to choose this profession (Budakoğlu, Özkan, Maral, Bumin, \& Aygün, 2002). Again similarly, Genç, Kaya, and Genç's (2007) study indicates that the most important factor for students to choose medicine is "the wish to help patients" (86.2\%) (Genç et al., 2007).

Our study compared students' achievement status, their expectations and satisfaction status. It was found that students who received higher scores from SSPE felt more negatively about satisfaction of their expectations than students who received lower scores. Unlike other segments of society, university students have many concerns including satisfaction of their expectations by the university and employment in the future. According to research by Gizir et al. (2010), 47\% of the students of Mersin University make a living with income that is much lower than minimum wage. One third of them stay with their families whereas only a few stay at state dormitories; many expressed that the main problem they face during studying is economic difficulties (Gizir et al., 2010). Considering the similarities between socio-economic statuses of the students in our study, this situation hinders benefitting from facilities of modern life. Our research sample Mersin University Medical Faculty's curriculum has 1822 theoretical and 376 practical course hours for the first three grades. For the third grade, there are 668 theoretical and 61 practical course hours. Third grade courses include ethics, medical pharmacology, nuclear medicine, medical pathology, radiology, medical biochemistry, medical microbiology and 20 different theoretical courses concerning surgical and internal sciences. In addition, the curriculum consists of more practical and professional training-oriented courses than first and second grades. Education in medical faculties is both longer and busier than courses in other faculties. Students in these faculties have to study devotedly to become successful (Öğenler \& Selvi, 2014). It might be that successful students focus on achievement more in such a busy and concerned period, and feel that their expectations are not satisfied. 
Quality medical education depends on both quality in design and process. It is both related to the design to satisfy student needs (an academic program) and to the process (for example curriculum, tools and materials, planning and other factors affecting the program). Our study indicated that students mostly focused on results rather than process; therefore, they made more assessments about the process. Similarly in educational organizations, outputs (evaluation of results) and quality in design (curriculum design) is paid more attention (Tezsürücü \& Aybarç-Bursalığlu, 2013).

Quality assurance, which has become a very important concept in educational institutions, generally refers to a systematic following and evaluation of a project/ service/institution in order to insure that quality standards are met (Özer, Gül, \& Küçükcan, 2010). Quality assurance is valid for all process concerning activities such as instruction, research, publications, academic achievements and project development in higher educational institutions. It is used for achievement of aims and strategies of higher educational institutions. It is measured through an "internal supervision" system and generally evaluated by national quality assurance agencies through an "external supervision" system (Özer et al., 2010). Our study was not conducted to supervise; rather it consists of questions asked during a class to create an awareness about devotion to a profession in terms of quality standards. It aims to identify a situation concerning expectations and satisfaction of individuals who receive a service.

In order to comment on quality of a service, first of all people, who benefit from this service, should be consulted. In this context, in institutions that provide educational medical services, education quality or productivity of an educational unit should be asked from the students who receive education. However, it is a prerequisite that the method of assessment must be scientifically accurate, valid and credible. Open ended questions of our study are important because they lack determinants that might lead students to certain answers; instead they allowed students to express the opinions that first come to their minds. In terms of student expectations and their satisfaction about quality standards in education, only three titles out of nine were expressed. This is a significant finding with regard to awareness of quality standards. Evaluation of expectations in the context of moral values can be seen as a parameter that might make measurements difficult.

Satisfaction of student expectations might change as students' awareness levels about quality increase. Students should be informed about quality education before they enroll in universities. In order to evaluate concretely, they should know about inadequacies and positive properties. Thereby the receiver of a service might increase his or her influence over educators or institutions. In this sense, students may make more conscious choices concerning universities. Medical faculty students are exposed to pressure concerning expectations of self-denial, sacrifice, thinking of other people 
more than themselves, and pursuing their work always at the maximum level. The profession of doctorship requires intensive moral values; therefore, students can make realistic and credible comments only if they are informed about the quality standards of this profession.

Finally, it is predicted that this pilot study might contribute positively to the status of students' satisfaction of their expectations. Moreover, it is considered that this study will contribute to the development of a proper curriculum which is compatible with quality standards to improve students as capable doctors in line with medical ethical principles.

\section{References}

Budakoğlu, İ., Özkan, Ö., Maral, I., Bumin, M. A., \& Aygün, R. (2002). Gazi Üniversitesi Tıp Fakültesi öğrencilerinin tıp eğitimine ilişkin görüşleri [Gazi University Faculty of Medicine of the medical education on students' views]. Toplum ve Hekim, 17(3), 189-194.

Doğan, E. (2002). Eğitimde toplam kalite yönetimi [Total Quality Management in Education] (2nd ed.). Ankara, Turkey: Academyplus Yayınlar.

Ekinci, E., \& Burgaz, B. (2007). Hacettepe Üniversitesi öğrencilerinin bazı akademik hizmetlere ilişkin beklenti ve memnuniyet düzeyleri [The expectation and satisfaction levels of the students at Hacettepe University with respect to academic services]. Hacettepe Üniversitesi Eğitim Fakültesi, 33, 120-134.

Genç, G., Kaya, A., \& Genç, M. (2007). İnönü Üniversitesi Tıp Fakültesi öğrencilerinin meslek seçimini etkileyen faktörler [Factors affecting career choice of Medical Faculty students at Inonu University]. Inönü Üniversitesi Eğitim Fakültesi Dergisi, 8(14), 49-63.

Gizir, C. A., Gizir, S., Aktaş, M., Göçer, S., Ömür, S., Yüce, G., \& Kırık, N. C. (2010). Mersin Üniversitesi ögrenci profili [Mersin University student profile]. Mersin, Turkey: ME.Ü. PDR Merkezi. Retrieved from http://www.mersin.edu.tr/ meui/psikolojik-danisma-ve-rehberlik-birimi/basinda-pdrm

Gültekin, B. K., Söylemez, A., Dereboy, İ. F., \& Çiçek, C. (2006). Ege ve Adnan Menderes Tıp Fakültelerinde uzmanlık eğitimi; tıpta uzmanlık öğrencisi bakış açicı ile [Residency training at Medical Schools of Ege and Adnan Menderes Universities: The residents' perspective]. Adnan Menderes Üniversitesi Tip Fakültesi Dergisi, 7(2), 17-21.

Koçel, T. (1999). İşletme yöneticiliği, yönetim organizasyonlarda davranış, klasikmodern-çağdaş ve güncel yaklaşımlar [Business management, management and organizational behavior, classical-modern-contemporary and actual approaches]. İstanbul, Turkey: Beta Yayınları. 
Lilley, P. M., \& Harden, R. M. (2003). Standards and medical education. Medical Teacher, 25, 349-51.

Öğenler, O., \& Selvi, H. (2014). Variables affecting medical faculty students' achievement: A Mersin University sample. Iranian Red Crescent Medical Journal, 16(3), e14648. http://dx.doi.org/10.5812/ircmj.14648

Öner, E. (2007). Kalite güvencesi - ders notlarl [Quality assurance - lecture notes]. İstanbul, Turkey: Marmara Üniversitesi Teknik Eğitim Fakültesi.

Özdemir Turan, S. (2005). Tip eğitimi ve standartlar [Medical education and standards]. Uludağ Üniversitesi Tip Fakültesi Dergisi, 31(2) 133-137.

Özer, M., Gül, B. S., \& Küçükcan, T. (2010). Yükseköğretimde kalite güvencesi [Quality assurance in higher education]. Ankara, Turkey: SETA Yayınları.

Sayek, İ., Odabaşı, O., \& Kiper, N. (2010). Türk Tabipler Birliği mezuniyet öncesi ttp eğitimi raporu 2010 [Turkish Medical Association undergraduate medical education report 2010]. Ankara, Turkey: Türk Tabipler Birliği Yayınları.

Tezsürücü, D., \& Aybarç Bursalığlu, S. (2013). Yükseköğretimde değişim: Kalite arayışları [Change in higher education: Quality searching]. Kahramanmaraşs Sütçü Imam Üniversitesi Sosyal Bilimler Dergisi, 10(2), 97-108.

The World Medical Education Federation. (2007). Dünya tıp eğitimi federasyonu tıp eğitiminde niteliğin geliştirilmesi için evrensel standartlar Avrupa spesifikasyonlar [World Federation for Medical Education for Improving Quality in Medical Education Global Standards European Specifications]. (Niteliğin sağlanmas1 çalışma grubu). Copenhagen Üniversitesi.

Türk Dil Kurumu.(n.d.).Nitelik[Quality]. Retrieved from http://www.tdk.gov.tr/index. php?option=com_gts\&arama=gts\&guid=TDK.GTS.5502cec59ec097.06924197 